\title{
Workfare redux? Pandemic unemployment, labour activation and the lessons of post-crisis welfare reform in Ireland
}

Workfare redux

\author{
Michael McGann \\ Maynooth University Social Sciences Institute, \\ National University of Ireland Maynooth, Maynooth, Ireland \\ Mary P. Murphy \\ Department of Sociology, National University of Ireland Maynooth, \\ Maynooth, Ireland, and \\ Nuala Whelan \\ Maynooth University Social Sciences Institute, \\ National University of Ireland Maynooth, Maynooth, Ireland
}

\begin{abstract}
Purpose - This paper addresses the labour market impacts of Covid-19, the necessity of active labour policy reform in response to this pandemic unemployment crisis and what trajectory this reform is likely to take as countries shift attention from emergency income supports to stimulating employment recovery.

Design/methodology/approach - The study draws on Ireland's experience, as an illustrative case. This is motivated by the scale of Covid-related unemployment in Ireland, which is partly a function of strict lockdown measures but also the policy choices made in relation to the architecture of income supports. Also, Ireland was one of the countries most impacted by the Great Recession leading it to introduce sweeping reforms of its active labour policy architecture.

Findings - The analysis shows that the Covid unemployment crisis has far exceeded that of the last financial and banking crisis in Ireland. Moreover, Covid has also exposed the fragility of Ireland's recovery from the Great Recession and the fault-lines of poor public services, which intensify precarity in the context of low-paid employment growth precipitated by workfare policies implemented since 2010. While these policies had some short-term success in reducing the numbers on the Live Register, many cohorts were left behind by the reforms and these employment gains have now been almost entirely eroded.

Originality/value - The lessons from Ireland's experience of post-crisis activation reform speak to the challenges countries now face in adapting their welfare systems to facilitate a post-Covid recovery, and the risks of returning to "workfare" as usual.
\end{abstract}

Keywords Covid, Pandemic unemployment, Activation, Workfare, Welfare reform

Paper type Conceptual paper

\section{Introduction}

Covid-19 represents far more than a public health emergency. The lockdowns that have ensued have precipitated major recession and unprecedented levels of unemployment. Discussion of the impacts on welfare states has thus far largely focused on social protection, and the income supports that have been established to mitigate the financial hardship of lockdown. Welfare states have implemented major adjustments to balance between what Brodkin and Larsen (2013, p. 60) characterize as the "regulatory, compensatory, and enabling" dimensions of welfare. Welfare's regulatory dimension encompasses the behavioural conditions attached to receiving payments, which in turn function as "compensatory" mechanisms for reducing the impact of market-derived inequalities. "Enabling" welfare, on the other end, captures those policies such as wage subsidies and 
IJSSP

$40,9 / 10$

964

training programmes that support "individuals to participate in the labour market on more favourable terms than the market alone would allow" (Brodkin and Larsen, 2013, p. 60). When the accent of welfare provision is on behavioural conditionality for residual payments, welfare systems function as regimes for commodifying labour and obligating citizens to work. This has been an unfolding trend across OECD countries for over 30 years (Greer, 2016), but particularly since the financial crisis.

As Theodore argues, once the initial shock of financial collapse subsided, the Great Recession quickly became "a crisis that would not be wasted" (2019, p. 4). Many countries responded to the twin challenges of high unemployment and growing fiscal deficits by recalibrating their welfare systems around a "workfare" activation model; an approach that "diagnoses the problem as too much reliance on welfare, emphasizes individual responsibility, and identifies the solution as sanctions applied to the failure to find, or prepare oneself for, paid work" (Evans, 2007, p. 31). This behavioural turn was conjoined with regressive cuts to social spending and was most pronounced in Britain, where the crisis was followed by sweeping changes to eligibility conditions that sharpened an already "systemic trend towards liberal paternalism" (Edmiston, 2017, p. 263). Universal credit extended conditionality to working claimants and their partners, and sanctions were toughened to allow the withdrawal of benefits for up to three years (Wright and Dwyer, 2014).

Even European countries with purportedly more "enabling" models oriented by human capital development used the crisis to reconfigure their systems towards "promoting the demanding elements of activation" (Seikel and Spannagel, 2018, p. 247). In an early analysis of the shifting reform trajectory in Europe, Brodkin and Larsen observed "emerging tendencies toward more of a US style workfare approach" (2013, p. 63), with Umney et al. interpreting this as "a by-product of austerity" in that training schemes to combat social exclusion are more expensive than job-search assistance targeted at the job ready while "sanctions reduce benefits payments" (2018, p. 345). For example, the Sarkozy government reformed France's minimum income system in 2009 to incorporate stronger job-search conditionality and a tighter focus on work-first activation. Likewise, Germany introduced cuts to unemployment benefits and services under the 2012 federal budget although it had already moved towards workfare under the 2005 Hartz IV reforms, which tightened eligibility criteria for unemployment assistance and linked payments to job-search conditionality (Lødemel and Gubrium, 2014). Elsewhere, in Denmark and the Netherlands, the pursuit of "flexicurity" polices stalled as the trajectory of reform became "driven more by austerity and "work-first" demands" (Bekker and Mailand, 2019, p. 153).

Covid has temporarily arrested this workfarist orientation of welfare policies. Over March and April, job-search conditionality requirements and sanctions for non-compliance were lifted in several countries including France, Germany and Sweden (OECD, 2020c). The activation regimes of liberal welfare states were particularly impacted. Regulatory demands inherent in those countries' social security systems were all but suspended, while compensatory benefits were increased in value and coverage. In Australia, the introduction of a coronavirus supplement of AUD $\$ 550$ per fortnight doubled the amount received by recipients of unemployment benefits overnight, while the country's "mutual obligations" regime was suspended until August (Remeikis, 2020). In the UK, workconditionality requirements were suspended for three months, and out-of-work payments were modestly increased by $£ 20$ per week; a removal of conditionality "extraordinary in political and policy terms" (Edmiston et al., 2020). Ireland took the unusual step of introducing a new emergency Pandemic Unemployment Payment (PUP), reserved for those who became unemployed on, or after, 13 March 2020. The individualized basic income payment of $€ 350$ per week can be compared to emergency payment schemes introduced in other liberal welfare regimes, such as Federal Pandemic Unemployment Compensation in the United States and Canada's Emergency Response Benefit, a temporary programme that delivered aid to 
7.3 million Canadians where, like PUP, eligibility was ex-post (Beauchamp, 2020). At the height of lockdown in late April and early May, almost 600,000 people were receiving the PUP costing $€ 206$ million per week (DEASP, 2020a).

As economies reopen, the focus of welfare recalibration will necessarily shift from cushioning the financial impacts of job displacement to adapting activation policies to stimulate labour market re-entry. In this article, we highlight the emerging pandemic unemployment crisis and consider the trajectory that post-Covid activation reform may take. Our analysis focuses on the Irish welfare state as an illustrative case while situating Irish developments within the wider international context to provide broader insights about activation reform in recessionary times.

Ireland is an interesting case for several reasons. Post-Brexit, Ireland will be the only EU Anglophone, or liberal welfare state. Historically a relatively hybrid model, Ireland is an informative place from which to observe welfare trajectories and may be particularly relevant for other small open European economies, particularly those in the Eurozone. The degree to which Ireland was one of the hardest hit by the 2008 financial crisis, and subsequently became the poster child of recovery, highlights its relevance for examining how the previous crisis and consequent policy directions impacted on its capacity to cope with the pandemic. In particular, Ireland's perceived strong recovery from the last crisis makes it an interesting case, in particular the role that rapid transformation of its welfare institutions played in coping with a surge in long-term unemployment, embracing both "workfare" activation and social services marketisation at a speed rarely seen in other countries (Dukelow and Kennett, 2018; Murphy, 2016), offers an important point for reflection. However, as we argue, the Covid-crisis has exposed underlying fault-lines of Ireland's "low road" recovery model in relation to labour market insecurity and weak investment in public services.

While Ireland does not feature widely in discussions of the comparative public health impacts of Covid-19, the Irish labour market has been very severely affected by the Covidcrisis due to a combination of strict lockdown measures, it's policy choices concerning emergency income supports, as well as structural features of Ireland's open, service-oriented economy. The particular Irish architecture, which relies more on income supports than public services to enable people to "stay home to save lives", offers a specific opportunity to understand how and why underlying fault-lines in a country's welfare state can prompt new departures in welfare policy which may or may not create their own path dependencies.

Covid-19 is a recent phenomenon, and constantly changing policy responses translate into significant data tracking challenges. This article therefore utilises a different methodological approach than a classic research methodology. Rather than reporting primary research findings, it reviews academic and grey literature along with available secondary quantitative data, with Ireland as the context and Covid-19 as the object of interest. By providing a synthesis of the available information and current research and reasoning in relation to concepts and theories of active labour policy reform, our analysis sheds light on the potential trajectories as well as likely societal impacts of further workfare-oriented social policy responses to recession, not just for Ireland but more generally in a European and wider context.

We proceed by documenting the labour market impacts of the Covid-crisis, before reviewing how activation policies were reoriented in response to the last unemployment crisis, the Great Recession, when a climate of fiscal austerity reduced already poor public services and a steep rise in unemployment was the context that facilitated an institutional reconfiguration of Ireland's welfare state. Although these activation reforms had some shortterm success in reducing overall claimant numbers, they did so at the expense of intensifying the dynamic of low-paid work and aggravating broader socio-economic inequalities with the result that many cohorts of citizens were left behind by the reforms. We argue that the Covidcrisis has wiped out employment gains from labour activation while exposing the fragility of 
IJSSP

$40,9 / 10$

Ireland's reconfigured welfare state architecture in the face of major economic downturn. A key concern in the context of any post-Covid recovery is whether vulnerable groups who were left behind by workfare reforms following the Great Recession will be re-forgotten, as the focus shifts to dismantling the "protective' capacity of the welfare state" (Dukelow and Kennett, 2018, p. 497).

\section{6}

\section{The Covid unemployment crisis}

The Covid-related unemployment crisis has been sharp and fast. Even countries with milder outbreaks, such as Australia, experienced mass employment disruption with the number of people receiving job-seeking payments doubling to 1.6 million Australians between December 2019 and April 2020 (Hutchens, 2020). In the UK, one of the countries most impacted by Covid, the lockdown measures precipitated an economic shock "unprecedented in modern history in its size and speed" (Wilson et al., 2020, p. 7). By early April, the unemployment rate had risen to $7.5 \%$ and, despite the 8.5 million workers on furlough (see below), was still higher already than the peak levels reached during the Great Recession (Wilson et al., 2020). Across Europe, a spring economic forecast estimated that the Covidcrisis was already the deepest recession in EU history. Impacts were asymmetric across member states, with 2020 unemployment levels forecast to vary from below 6\% in several countries (Netherlands, Germany, Australia, Denmark) to above 18\% in Spain and Greece (European Commission, 2020).

However, unemployment figures reveal only a fraction of the employment disruption wrought by the pandemic. Partly, this is because, due to the shuttering of economies, vast proportions of displaced workers are not actively job-searching but waiting to return to jobs that may or may not resume. As such, they do not meet the technical definition of unemployment, which requires people to be available for work and to have job-searched within the previous four weeks. Another reason why unemployment data conceal the impact of Covid on labour markets relates to the hundreds of thousands who have remained on payrolls through short-time work (or furlough) schemes, such as Germany's Kurzarbeit scheme which was expanded to cover temporary and agency workers, and to fund $100 \%$ of employees' social insurance contributions compared with $50 \%$ before the pandemic. Italy and France similarly extended their short-term working schemes to all workers, along with limiting economic dismissals to encourage companies to avoid laying off workers (OECD, 2020b). The UK created an entirely new short-time work scheme, the Job Retention Scheme, which covered $80 \%$ of the wages of employees' (up to $£ 2,500 /$ month) whose work was disrupted by lockdown measures. By late May, about 8.7 million workers had been furloughed under the scheme (ONS, 2020): more than two-and-a-half times the number of new Universal Credit claims (3.2 million) made between mid-March and June (Edmiston et al., 2020). This ensured that the rise in unemployment was more modest than in some other countries', although Mayhew and Anand (2020, p. 2) also caution that the JRS has merely delayed a steep rise in unemployment until subsidies are unwound later in 2020. In Ireland, the use of furlough schemes has been more modest, and new claimants have, from the start, been factored into a "Covid-adjusted" unemployment rate, providing a more realistic assessment of the employment impacts of the pandemic.

\section{Ireland's pandemic unemployment crisis}

Ireland introduced one of the strictest lockdowns in Europe (Hale et al., 2020). On 12 March, just one day after the first confirmed Covid-death, all childcare and educational institutions were closed, followed by pubs on 15 March and all other non-essential businesses on 27 March (Beirne et al., 2020). Not until 18 May did some outdoor retailers such as garden centres 
begin to re-open. Further lockdown measures were eased on 8 June, although it was not until 29 June that most economic sectors were permitted to reopen and citizens could travel beyond county borders. Although resurgence of the virus over the summer of 2020 meant that the full economy never reopened and regional lock downs became a feature of "living with the virus".

The conservative pace of re-opening was partly driven by the Government's adoption of a two-metre distancing rule, in comparison to other countries opting for a one-and-a-half (Germany, Italy) or one-metre (France, Denmark) rule. This hindered the re-opening of service sectors, along with educational institutions, and the government has come under increasing pressure to resist the National Public Health Emergency Team's (NPHET) social distancing advice. The advisory body has exerted enormous influence over Ireland's Covid response. It has been accused of "running the country" during the early stages of the pandemic, when a slow government formation process (20 February to 26 June) precipitated a caretaker government and weak cabinet that was perceived as unwilling to act contrary to NPHET's advice (O'Connel and Sheehan, 2020).

Beyond the austerity of its lockdown, Ireland also experienced a severe rise in unemployment from 5\% in early March to a "Covid-19 adjusted" unemployment rate of $28.2 \%$ by late April, dropping to $16.7 \%$ in July (CSO, 2020a, 2020b). This figure includes both officially unemployed workers and those displaced onto the PUP, who may not be actively job-searching. This unusual method of reporting unemployment figures gives Ireland a more accurate indication of the level of job displacement wrought by Covid.

As elsewhere, the impacts of lockdown measures have been "markedly asymmetric" across various groups of workers. More generally across Europe, Pérez et al. (2020) observe that key economic sectors, such as hospitality and personal services, that were closed during the early stages of the pandemic were often "characterised by low wages and precarious conditions of employment" with high concentrations of women and young workers. Ireland is no exception, with an early analysis finding that those who were laid-off were "more likely to be young, low-skilled, female and part-time than the population average" (Coates et al., 2020, p. 33). The downturn has been particularly sharply felt by younger and low-paid workers, with unemployment among those under 25 rising to a Covid-adjusted unemployment rate of $62 \%$ in May 2020, dropping to $41 \%$ in July 2020 (CSO, 2020b). More than a fifth of PUP claimants came from Accommodation and Food Services which, along with the Wholesale and Retail Trade and Construction sectors, accounted for approximately half of PUP recipients (Coates et al., 2020). These are all also among the four lowest paid sectors in the Irish economy. By late April, more than a quarter of Wholesale and Retail workers, almost half of Construction workers and two-thirds of Accommodation and Food Services workers had lost their jobs (Coates et al., 2020). By early May, over 1.26 million Irish workers were fully or partially dependent on welfare, including: almost 215,000 people on the Live Register, more than 450,000 furloughed under the Temporary Wage Subsidy Scheme and almost 590,000 receiving the PUP (DEASP, 2020a). In addition, it is estimated that a further 565,000 people of working-age were receiving other state income supports such as Disability and Carers payments, taking the number of working-age people reliant in income support to almost 1.8 million out of a total working-age population of just under four million and a labour force of 2.47 million (Murphy et al., 2020; CSO, 2020c).

\section{Why Ireland's unemployment crisis was so deep?}

Several factors explain why pandemic unemployment reached such a high level in Ireland. One reason is the severity of lockdown measures and slow pace of re-opening. This can be partially attributed to a political vacuum and the degree to which underdeveloped public services, a feature of Ireland's welfare architecture, afforded limited room to manoeuvre to accommodate social distancing requirements (e.g. small classroom sizes, high studentteacher ratios). Ireland's small open economy also makes the country highly exposed to 
IJSSP

$40,9 / 10$

968

global market volatility, fluctuations in international trade and "boom-and-bust" cycles. Another feature of the Irish economy is the size of its services sector, meaning that a high proportion of workers were vulnerable to being shuttered. According to an early study by Fana et al. (2020), just under $13 \%$ of Irish employees were employed in sectors that were almost entirely closed and unable to operate via teleworking, such as hospitality, real estate services, leisure and recreation services. This compared with an average of below $10 \%$ across EU countries.

The policy choices made in relation to income supports may have also contributed to the rise in unemployment. Where furlough payments were widely used to retain workers in jobs by other countries, Ireland prioritised the establishment of a quasi-basic income scheme, the PUP. Unlike conventional income supports, the PUP was not means-tested and offered a generous income replacement rate of $€ 350$ per week (LMAC, 2020). Controversially, people who were claiming social assistance payments prior to 13 March remained on Jobseekers' Allowance (JA), receiving a household means-tested payment rate for a single person of either $€ 203$ per week, or just $€ 112.50$ per week for those under 25 .

The PUP was not introduced in isolation, however. Like other countries, Ireland implemented a Temporary Wage Subsidy Scheme (TWSS) in late March. However, unlike the PUP's administrative simplicity, it was complex in design. Initially, the scheme subsidised up to $70 \%$ of net wages up to $€ 410$ per week. However, a lower subsidy of $€ 350$ per week was paid to employees with net earnings above $€ 586$ per week, while those with net earnings above $€ 960$ per week were ineligible. Consequently, in its early design, a significant proportion of displaced workers were either no better off or perhaps even worse off on the TWSS than they would've been on the PUP (Beirne et al., 2020). In May, a series of changes were introduced to increase the range of workers eligible for the TWSS, although the number of PUP recipients continued to eclipse the number of workers supported through the TWSS until early June (DEASP, 2020c).

As Ireland's economy has begun reopening, issues around the PUP payment rate and disincentives to work have come to the fore. One early analysis found that the PUP was $50 \%$ higher than the average gross weekly earnings of minimum wage earners in the retail, accommodation and food work sectors (Redmond, 2020). Accordingly, in June, the PUP was converted into a two-tiered payment whereby those with pre-Covid earnings below $€ 200$ per week would receive payments equivalent to the JA, while all remaining claimants would receive $€ 350$ per week. Further changes were announced under the Government's July Stimulus package, which extended the PUP until April 2021 but introduced further tapering measures from mid-September when the payment will be closed to new entrants (DEASP, 2020b). By April 2021, the government intends to have tapered the PUP back to JA rates, although the full mechanisms to do this are not entirely clear.

The extension of the PUP suggests policy officials believe the disruption to employment wrought by Covid-19 will remain "large-scale and long-term" (LMAC, 2020, p. 12). Following the Great Recession, it took more than a decade for the unemployment rate to recover to precrisis levels. The proportion of workers displaced by Covid is much higher this time and, as the OECD warns, the "legacies" of Ireland's experience of the last financial crisis, including weak bank profitability and high household and general government debt, are likely to "temper the speed of recovery" from OCED (2020a, p. 235). Ireland's Labour Market Advisory Council has cautioned that any reorientation of active labour programmes "will be very challenging" given the scale of increased demand and "potential increase in the numbers of workers who will remain unemployed" (2020, p. 22). To meet this increased demand, the government committed an additional $€ 100 \mathrm{~m}$ to activation measures under its July stimulus package, with the bulk of this investment going towards enhancing the capacity of the Public Employment Service and contracted providers to deliver job-search assistance (DEASP, 2020b). As reviewed below, this institutional capacity to deliver job-search assistance is a 
legacy of how Ireland reformed its welfare system after the last unemployment crisis to embed a focus on workfarist activation. An outstanding concern in the context of any postCovid recovery is what will happen to the labour market re-integration of the long-term unemployed and other disadvantaged social groups who are so frequently left behind by the "low road" nature of active labour policy responses to recession.

\section{Active labour policies in recession: Ireland's "workfarist" turn}

In Ireland, the Great Recession brought about a fundamental shift in the institutional rationality of the welfare state towards labour (re)commodification (Boland and Griffin, 2015; Dukelow and Considine, 2014; Murphy, 2016). Before then, Ireland was considered "an outlier" (Millar and Crosse, 2018, p. 114) among OECD countries in activation terms. Its welfare system was largely "passive" in orientation. The only "active" labour measures were optional training and work-experience programmes, and FAS, the national labour exchange. These were highly fragmented and siloed from benefits administration. Conditionality was weakly applied, and claimants could generally receive benefits without any requirement to participate in re-employment services (Martin, 2015). However, the combination of a threefold increase in unemployment, collapse in state revenues and gaining policy influence of the Troika (EU, ECB and IMF) provided a policy window for a programme "of rapid "modernistation"' (Dukelow and Considine, 2014).

As elsewhere, the financial crisis was reinterpreted as a fiscal and debt crisis to legitimate "austerity and the rapid transformation of the welfare system" (Boland and Griffin, 2015, p. 35). Cuts to working age payments were introduced under the 2010 and 2011 Budgets. The number of qualifying contributions required for social insurance payments was also doubled and the duration of entitlement "significantly curtailed" (Dukelow and Considine, 2014, p. 63). At the same time, the rate of social insurance contributions paid by employers for workers earning less than $€ 376$ per week was halved, from $8.5 \%$ to $4.25 \%$, as part of a new Jobs Initiative (O'Sullivan et al., 2017). These changes were accompanied by new "penalty rates" (amounting to $25 \%$ of total payments and payment suspensions for up to nine weeks) for claimants who failed to comply with conditionality requirements outlined in a new Pathways to Work activation strategy. Claimants became obligated to meet with caseworkers for regular job-search assistance, and to sign a "personal progression plan" outlining how they would enhance their employability. These policy changes were accompanied by significant operational and administrative reforms of public employment services. Beginning in 2012, the national employment service was merged with social welfare offices to consolidate income supports and activation measures into a single Intreo service. The use of contracted agencies to provide employment services was also greatly expanded through the commissioning of JobPath in 2015, a Payment-by-Results quasi-market in employment services for long-term claimants. While unemployed claimants were the primary targets of activation, lone parents also became targeted through changes to the eligibility conditions for the One Parent Family Payment (OPFP). The qualifying age of lone parents' youngest child was progressively reduced from 22 to 7 years of age, resulting in tens of thousands of lone parents being migrated onto jobseeking payments (Millar and Crosse, 2018).

The overall demandingness of activation remains light in Ireland, although there has been a discernible shift towards a more punitive approach. In 2017, 16,450 sanctions were applied to claimants compared with about 1,500 in 2012 and despite a substantial decline in claimant numbers during this period (Cousins, 2019). Meanwhile, cuts to other service areas as part of a wider programme of austerity have also intensified pressures on lone parents and other claimants to work through a process of what Dukelow and Kennett (2018) describe as "coercive commodification". Most notably, public investment in social housing fell by $94 \%$ over the period from 2008 to 2013 and the private rental sector has subsequently become the 
IJSSP 40,9/10

970

primary site of social housing provision through the Housing Assistance Payment and Rebuilding Ireland strategy. This has had knock-on effects on the private rental market, excluding many poorer households due to a "[l]ack of overall supply and private sector rent increases" (Murphy, 2020, p. 257).

\section{Activation - for whom?}

Ireland's reorientation of activation policy was propelled by a surge in the number of claimants on the Live Register - from 158,752 in January 2007 to a peak of 470,284 in July 2011 (DEASP, 2019, p. 12) - in the context of a growing fiscal deficit. It was predominantly aimed at reducing welfare caseloads via the shortest route possible, rather than addressing social exclusion or enabling a right to sustainable employment in decent work. In this, the reforms had some success although significant cohorts were also left behind by the policy emphasis on activation via job-search conditionality. One notable aspect was the dominance of a male breadwinner-shaped activation. As Figure 1 shows, the number of women on the Live Register for one year or more was higher in February $2020(27,604)$ than in October 2009 $(23,399)$ - the earliest point that data on duration of registration are available - while the total number of long-term claimants declined only marginally: from 87,414 claimants in October 2009 to 66,871 claimants in February 2020. These data suggest that Ireland's activation reforms had far less success in tackling enduring labour market exclusion than they had in resolving acute, crisis-unemployment among men.

Compared with other EU countries, rates of employment among disadvantaged social groups such as people with disability and lone parents remain very low in Ireland. In the case of lone parents, although the employment rate increased from $46 \%$ in 2012 to $58 \%$ in 2017 ,

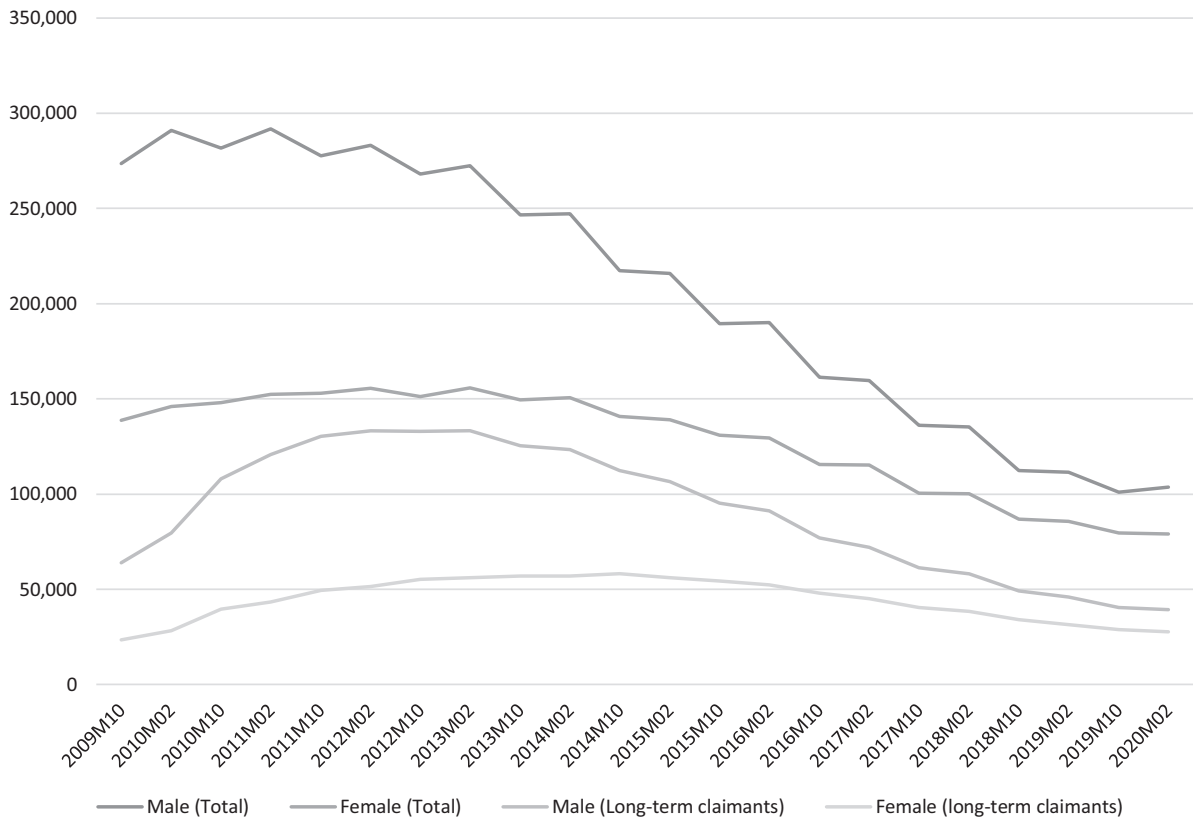

Claimants by gender and duration of registration, October 2009 to February 2020

Source(s): Data extracted from Central Statistics Office database, data series LRM11: Persons on the Live Register by Age Group, Sex, Duration and Month 
this remained among the lowest lone parent employment rates out of all EU-15 countries (SVP, 2019). It was also accompanied by a sharp increase in rates of in-work poverty among lone parents, from below 9\% in 2012 to almost 21\% in 2017 (SVP, 2019, p. 28), suggesting that activation reforms pushed many lone parents into in-work poverty. Millar and Crosse (2018) argue that activation is no panacea for poverty among lone parent households in Ireland, especially given the high costs of child-care which is predominantly delivered via market providers. One study, drawing on a survey of almost 3,700 affected claimants, found that although more lone parents transitioned to full-time employment as a result of changes to the OPFP payment, almost half "saw a drop in their income and rates of deprivation were above 80\%” (INDECON, 2017; cited in SVP, 2019, p. 12).

The reality of activation pushing parents into in-work poverty mirrors wider international research, with two recent longitudinal studies of UK claimants' experiences of activation and conditionality (the Welfare Conditionality and Lived Experience studies) finding that the transition from out-of-work to in-work poverty was a common experience among participants in both studies (Wright and Patrick, 2019). As Seikel and Spannagel argue in a study of the intersection between activation reforms and in-work poverty in Europe, "creating more jobs does not automatically lead to less in-work poverty, as hoped for by policy-makers" (2018, p. 257). While workfare style programmes can be effective for "those who are relatively jobready", continuous doubts remain about the quality of employment with Martin observing in a review of OECD policies that many are "activated to take low-wage jobs. . . which may not lift them and their families permanently out of poverty" (2015, p. 22). More generally, international evidence on the effectiveness of workfare policies is mixed. In a meta-analysis of over 200 evaluations of ALMPs, Card and colleagues conclude that workfare programs tend to have large short-term effects for cohorts with few barriers other than unemployment. However, effects are more marginal for women and the long-term unemployed (Card et al., 2015, p. 24).

\section{Activation - for what?}

These observations about the uneven impacts of workfare and potential for transitions into in-work poverty bring into view long-standing concerns about the relationship between workfare and the wider political economy. Critics accuse workfarist policies of being regulatory strategies for "pimping the precariat" (Dean, 2012) that are concerned less with "creating jobs for people who do not have them" than "creating workers for jobs that nobody wants" (Peck, 2001, p. 6). This arises from how workfare redraws the boundaries between work and welfare to press claimants into joining what critical political economists, following Marx, term "the reserve army of labour" (Greer, 2016, p. 163). This reserve army constitutes a readily available supply of labour for employers in expanding areas of the economy, creating competition for jobs and enabling the cost of labour to remain low even in times of growth and prosperity. Workfare polices are argued to reinforce this mechanism by "ratchet[ing]-up" (Greer, 2016, p. 169) job competition and generally "resetting the terms for what constitutes acceptable work" (Brodkin and Larsen, 2013, p. 58). Standing identifies a "vicious circle" in which labour market flexibility leads to a proliferation of insecure jobs providing few incentives for claimants to enter employment. This then leads governments to tighten eligibility conditions and cut payments "to "make work pay" which, in turn, further erodes wages (Standing, 2011, p. 36). Peck and Theodore describe "a dialectical relationship" between workfare policies and the flexible labour markets in which they operate: where the former "exploit the conditions found in contingent job markets" to move people into work while simultaneously reproducing precarity through securing a "labour supply for insecure work" (2000, p. 123).

The trajectory of Ireland's recovery from the Great Recession illustrates this kind of "circular mobility" (Greer, 2016, p. 6). An analysis of employment growth over the period 
IJSSP

$40,9 / 10$

972

2012-2018 shows that while employment grew by 382,000 jobs over this period, more than $40 \%$ of this growth was concentrated in sectors "with above average risk of precariousness" (Nugent et al., 2019, p. 8) in terms of work uncertainty, low pay and limited entitlements. This risk of precarity is exacerbated by the extent of reliance on market provision to meet housing, child-care and other essential needs. This gives rise to flex-insecurity that leaves no cushion for those suddenly unemployed. Poor investment in public services marks Ireland out from other countries that pursued the same activation policies but have had better underlying architecture to enable the state to meet essential needs. Ireland's relatively early and restrictive response to the pandemic might be explained by a lack of choice in the absence of decent public services (schools, health, transport and above all child, elder and social care). Real per capita expenditure on public services is low (€7,200 compared to EU peer group average of $€ 8,400)$. The German state, while implementing Hartz IV workfare-oriented reforms, still spends $€ 8,400$ per capita on public services while the Danish state pursues flexicurity with public services expenditure of $€ 10,100$ per capita (OECD, 2016). Spending on public services needs to rise by $21 \%$ or close to $€ 9$ billion to reach Ireland's EU peer group average. In this context, income support-based policy responses like PUP become a likely emergency response for households displaced from employment but heavily reliant on market-based services for basic needs (Murphy, 2017).

The micro-mechanisms or microeconomics of labour market participation post-2008 work through a combination of weak employment protection regulation and tighter and recommodified income support rules: the intersection of these micro-mechanisms pushes or compels unemployed people into lower paid work. The numbers of Irish workers working variable part-time hours almost doubled between 2007 and 2014, before slightly declining in 2016, while the overall incidence of temporary workers rose from $8 \%$ in 2008 to $10 \%$ in 2013 (Muprhy, 2017). Nugent et al.'s analysis of employment growth and temporary work finds an increasing proportion of temporary contracts of less than one year in duration, from about $60 \%$ of temporary contracts in 2007 to over $63 \%$ of temporary contracts by late 2018. More worryingly, the incidence of involuntary" temporary workers - people on temporary contracts because they have been unable to find permanent work almost tripled from $14.1 \%$ of temporary workers in 2008 to over 39\% in 2017 (Nugent et al., 2019).

Low-paid work also rose substantially, with approximately $23 \%$ of Irish workers estimated to be low-paid - defined as wages below two-thirds of median income - in $2017 \mathrm{Ni}$ Aodha, 2019) compared with 20\% in 2010 (Logue and Callan, 2016). In conjunction with the rise in low-paid work, there has been a $20 \%$ increase in the numbers of workers experiencing in-work poverty: from 91,407 in 2009 to almost 110,000 in 2018 (SJI, 2020). Women, lone parents and younger workers are over-represented among the ranks of the low-paid. Over $60 \%$ of low-paid workers in 2013 were female, while $36 \%$ were under 30 - double the proportion of younger workers than in employment as a whole (Collins and Murphy, 2016). Sectorally, low-paid workers are concentrated in Wholesale and Retail trade (23.8\%) and in Accommodation and Food Services (18.1\%), with O'Sullivan et al. (2017, p. 14) attributing the growth of low-paid work in these sectors partly to "[s]tate policy on employer's social insurance" and discounted contribution rates paid in respect to low-waged workers. The concentration of low-paid work in these sectors is particularly significant given they constitute a greater proportion of indigenous employment in Ireland than other EU countries (O'Sullivan et al., 2017). They have also been the sectors most impacted by Covid-19, with pandemic unemployment tracking underlying fault-lines of precarity, low pay and inequality in the Irish labour market. In so doing, it has exposed the shallowness of the foundations upon which Ireland's recovery from recession was built, and the fragility of an activation model orientated by what Evan's terms “'job-poor” growth' (2007, p. 31). 


\section{Conclusion}

While individual state responses to Covid-19 reflect a variety of dynamics, including the power of interest group politics, political institutions, underlying values and states' position in the global economy, we have focused here on how social architecture and past reform trajectories can shape the range of policy responses to the pandemic and impact on welfare states and citizens. It might be argued that retrenchment and activation reforms following the last crisis have left countries such as Ireland with greater fiscal capacity to address the macroeconomic and unemployment challenges of the Covid-crisis. Entering the pandemic, Ireland's debt-to-GDP ratio was below the EU average, enabling the country to borrow at low interest rates to fund emergency welfare measures (Parliamentary Budget Office, 2020). However, the pursuit of austerity also left Ireland with under-funded public services and an increased reliance on market provision to meet housing and other essential needs. This weakened institutional capacity to adopt more flexible lockdown measures while necessitating emergency income supports to be set at high rates to enable citizens to continue to meet housing and other essential needs.

Our analysis of the impact of Covid-19 on Ireland's welfare state raises new questions about the direction of future welfare reform and the role of activation regimes in shaping policy responses. The levels of unemployment reached during the present crisis will become a challenge for the future of the Irish welfare state. As the pandemic transitions from a public health to an unemployment crisis, the necessity of active labour policy will come increasingly into view. We are witnessing a similar accumulation of conditions - a sharp increase in claimant numbers at a time of deepening recession - to those confronting countries in the wake of the financial crisis. The trajectory of activation labour policy reform following that crisis was underscored by a deepening commitment to labour commodification via benefit cuts, job-search conditionality and mandatory participation in low-cost activation programmes. The welfare reforms that have unfolded since 2010 are characteristic of this "low road" model, although Ireland is just one among several European countries that reconfigured their activation regimes in this direction following the Great Recession.

While the Covid crisis has temporarily disrupted the spread of workfare activation due to countries' momentarily enhancing the compensatory and enabling elements of welfare while suspending welfare's more demanding side, there is every reason to believe that countries will recommit themselves to workfare policies as attention shifts to reducing claimant numbers. Further analysis would be useful to examine experiences beyond European and liberal regimes (for example, in South America and Asian countries). However, the seeds of this shift are already being sown in Ireland by the foreshadowing of cuts to the PUP, tightening of eligibility conditions and policy attention on redesigning payments to incentivise "work at the margin, noting that the most severely impacted sectors have many workers on relatively low wages' (LMAC, 2020, p. 13). At the time of writing, the Irish government is proposing a Social Welfare (Covid-19) Amendment Bill that will legislate a requirement for PUP claimants to actively job-search, paving the way for claimants to be subject to benefit conditionality and sanctions. However, as we have argued, this approach to active labour policy reform priorities low-hanging fruit: moving the recently unemployed back into work at speed while doing little to address the labour market exclusion experienced by more disadvantaged citizens. There are also considerable social costs in terms of how workfare policies intersect with the regulation of contingent labour markets to grow low-paid economies and in-work poverty. In Ireland, this has been powerfully exposed by the magnitude and unequal impacts of pandemic unemployment on different groups of workers, with Covid-related job displacement tracking the contours of employment precarity in the Irish labour market.

Prior to Covid, there was an increasing recognition of the need for a further reorientation of activation policy to support the labour market inclusion of the longer-term unemployed and other cohorts such as lone parents and people with disabilities. As the Secretary of the Irish
Workfare redux 
IJSSP

40,9/10

Government's Department of Employment Affairs and Social Protection elaborated in evidence to a parliamentary committee, the primary focus of activation post-recession was to help those "on the live register to compete for such job vacancies as arise and reduce their individual duration of unemployment." But with the country moving into a period of relative prosperity that focus could shift to what he termed "active inclusion": "increasing active labour-market participation by all people of a working age. . . to offer greater support to people from non-jobseeker cohorts" (JCEASP, 2018, p. 6). Developing this idea, the Oireachtas Committee on Employment Affairs and Social Protection called for "active inclusion" to become central to future labour market policy development and for the government "to move away from its current work-first approach" (JCEASP, 2018, p. 32) towards a more rightsbased, "person-centred" approach. But although activation policies are often advocated as promoting social inclusion, the two are not always complimentary. As Perkins argues, rather than supporting inclusion, activation can "contribute to further exclusion" depending on how policies intersect with "the broader labour market context, and the extent to which this supports the creation of jobs with good wages and conditions at the lower end of the labour market" (2010, p. 281). Having highlighted the continuity between the reform to welfare provision post the Great Recession, and the fragility of the welfare state today to deal with a major pandemic, the question now is whether this will extend into future welfare architecture. The danger post-Covid is that momentum for a more inclusive approach to active labour policy development will be halted by a refocusing on activating the pandemically unemployed.

\section{Funding}

This research has received funding from the European Union's Horizon 2020 research and innovation programme under the Marie-Sklodowska-Curie grant agreement no. 841477. It has also been supported by the Irish Research Council under Grant IRC/COALESCE/2019/56/ MURPHY. The views expressed are those of the authors alone. Neither Maynooth University, the European Commission nor the Irish Research Council are responsible for any use that may be made of the information in this article.

\section{References}

Beauchamp, Z. (2020), “Canada succeeded on coronavirus while the US failed. Why?”, available at: https://www.vox.com/2020/5/4/21242750/coronavirus-COVID-19-united-states-canada-trumptrudeau (accessed 24 August 2020).

Beirne, K., Doorley, K., Regan, M., Roantree, B. and Tuda, D. (2020), The Potential Costs and Distributional Effect of Covid-19 Related Unemployment in Ireland, Economic and Social Research Institute, Dublin.

Bekker, S. and Mailand, M. (2019), "The European flexicurity concept and the Dutch and Danish flexicurity models: how have they managed the Great Recession?", Social Policy and Administration, Vol. 53 No. 1, pp. 142-155.

Boland, T. and Griffin, R. (2015), "The death of unemployment and the birth of job-seeking in welfare policy: governing a liminal experience", Irish Journal of Sociology, Vol. 23 No. 2, pp. 29-48.

Brodkin, E.Z. and Larsen, F. (2013), "The policies of workfare: at the boundaries between work and the welfare state, Brodkin, E.Z. and Marston, G. (Eds), Work and the Welfare State, Djorf, Copenhagen, pp. 57-68.

Card, D., Kluve, J. and Weber, A. (2015), "What works? A meta analysis of recent active labour market programme evaluations", Journal of the European Economics Association, Vol. 16 No. 3, pp. 894-931.

Central Statistics Office (2020b), "Monthly unemployment July 2020”, available at: https:/www.cso.ie/ en/releasesandpublications/er/mue/monthlyunemploymentjuly2020/ (accessed 25 August 2020). 
Central Statistics Office (2020c), "Labour force survey: quarter 1 2020”, available at: https://www.cso. ie/en/releasesandpublications/er/lfs/labourforcesurveylfsquarter12020/ (accessed 27 July 2020).

Central Statistics Office (CSO) (2020a), "Monthly unemployment April 2020", available at: https:// www.cso.ie/en/releasesandpublications/er/mue/monthlyunemploymentapril2020/ (accessed 11 June 2020).

Coates, D., Corcoran, D., Cronin, H., Brioscu, A., Byrne, S., Keenan, E. and McIndoe-Calder, T. (2020), The Initial Impacts of the Covid-19 Pandemic on Ireland's Labour Market, Department of Employment Affairs and Social Protection, Dublin.

Collins, M.L. and Murphy, M.P. (2016), "Activation: solving unemployment or supporting a low-pay economy?", Murphy, M.P. and Dukelow, F. (Eds), The Irish Welfare State in the Twenty-First Century: Challenges and Change, Palgrave Macmillan, Dublin, pp. 67-92.

Cousins, M. (2019), "Welfare conditionality in the republic of Ireland after the Great recession", Journal of Social Security Law, Vol. 26 No. 1, pp. 30-41.

Dean, H. (2012), "The ethical deficit of the United Kingdom's proposed Universal Credit: pimping the precariat?", The Political Quarterly, Vol. 83 No. 2, pp. 353-359.

Department of Employment Affairs and Social Protection (DEASP) (2019), "Evaluation of JobPath outcomes for Q1 2016 participants", available at: https://assets.gov.ie/36499/ ffdce98cddc34addb05cf41a70aaf4e7.pdf (accessed 19 June 2020).

Department of Employment Affairs and Social Protection (DEASP) (2020a), "Update on payments awarded for covid-19 pandemic unemployment payment and enhanced illness benefit", available at: https://www.gov.ie/en/press-release/a49552-update-on-payments-awarded-forcovid-19-pandemic-unemployment-paymen/ (accessed 12 June 2020).

Department of Employment Affairs and Social Protection (DEASP) (2020b), "Minister Humphreys announces $€ 2.3$ billion expenditure on income and employment supports as part of the July stimulus package", available at: https:/www.gov.ie/en/press-release/cbee8-minister-humphreysannounces-23-billion-expenditure-on-income-and-employment-supports-as-part-of-the-julystimulus-package/ (accessed 27 July 2020).

Department of Employment Affairs and Social Protection (DEASP) (2020c), "Update on payments awarded for COVID-19 pandemic unemployment payment and enhanced illness benefit", available at: https://www.gov.ie/en/press-release/77c06-update-on-payments-awarded-for-covid19-pandemic-unemployment-payment-and-enhanced-illness-benefit/ (accessed 12 June 2020).

Dukelow, F. and Considine, M. (2014), "Between retrenchment and recalibration: the impact of austerity on the Irish social protection system", Journal of Sociology and Social Welfare, Vol. 41 No. 1 , pp. 55-72.

Dukelow, F. and Kennett, P. (2018), "Discipline, debt and coercive commodification: post-crisis neoliberalism and the welfare state in Ireland, the UK and the USA", Critical Social Policy, Vol. 38 No. 3, pp. 482-504.

Edmiston, D. (2017), "Welfare, austerity and social citizenship in the UK", Social Policy and Society, Vol. 16 No. 2, pp. 261-270.

Edmiston, D., Baumberg, B., Scullion, L., Ingold, J. and Summers, K. (2020), "Despite the suspension of conditionality, benefit claimants are already looking for work", available at: https://blogs.lse.ac. uk/politicsandpolicy/conditionality-covid19/ (accessed 24 July 2020).

European Commission (2020), European Economic Forecast: Spring 2020, Publications Office of the European Union, Luxembourg.

Evans, P.M. (2007), "(Not) taking account of precarious employment: workfare policies and lone mothers in Ontario and the UK", Social Policy and Administration, Vol. 41 No. 1, pp. 29-49.

Fana, M., Tolan, S., Torrejón, S., Urzi Brancati, C. and Fernandez-Macias, E. (2020), "The COVID confinement measures and EU labour markets", doi: 10.2760/079230 (accessed 12 June 2020).

Greer, I. (2016), "Welfare reform, precarity and the re-commodification of labour", Work, Employment and Society, Vol. 31 No. 1, pp. 162-173. 
IJSSP 40,9/10

Hale, T., Webster, S., Petherick, A., Phillips, T. and Kira, B. (2020), "Oxford Covid-19 government response tracker", available at: https://www.bsg.ox.ac.uk/research/research-projects/ coronavirus-government-response-tracker\#data (accessed 12 June 2020).

Hutchens, G. (2020), "JobSeeker has about 700,000 more claimants than there are 'unemployed' people on ABS data", available at: https://www.abc.net.au/news/2020-06-19/unemployment-numbersstill-mask-the-true-scale-of-job-losses/12370940 (accessed 22 June 2020).

Joint Committee on Employment Affairs and Social Protection (JCEASP) (2018), Labour Activation, House of the Oireachtas, Dublin.

Labour Market Advisory Council (2020), Preparing for Economic Recovery, Department of Employment Affairs and Social Protection, Dublin.

Lødemel, I. and Gubrium, E. (2014), "Trajectories of change: activation reforms from inception to times of austerity", Lødemel, I. and Moreira, A. (Eds), Activation or Workfare? Governance and the Neoliberal Convergence, Oxford University Press, Oxford, pp. 289-326.

Logue, C. and Callan, T. (2016), Low Pay, Minimum Wages and Household Incomes: Evidence for Ireland, Economic and Social Research Institute, Dublin.

Martin, J.P. (2015), “Activation and active labour market policies in OECD countries: stylised facts and evidence on their effectiveness", IZA Journal of Labor Policy, Vol. 4 No. 4.

Mayhew, K. and Anand, P. (2020), "Covid-19 and the UK labour market”, Oxford Review of Economic Policy. doi: 10.1093/oxrep/graa017/5850129.

Millar, M. and Crosse, R. (2018), "Lone parent activation in Ireland: putting the cart before the horses?", Social Policy and Administration, Vol. 52 No. 1, pp. 111-129.

Murphy, M.P. (2016), "Low road or high road? The post-crisis trajectory of Irish activation”, Critical Social Policy, Vol. 36 No. 3, pp. 432-452.

Murphy, M.P. (2017), "Irish flex-insecurity: the post-crisis reality for vulnerable workers in Ireland", Social Policy and Administration, Vol. 51 No. 2, pp. 308-327.

Murphy, M.P. (2020), "Dual conditionality in welfare and housing for lone parents in Ireland: change and continuity?", Social Policy and Administration, Vol. 54 No. 1, pp. 250-264.

Murphy, M.P., Whelan, N., McGann, M. and Finn, P. (2020a), The 'high Road' Back to Work: Developing a Public Employment Eco System for a Post-covid Recovery, Maynooth University Social Sciences Institute, Maynooth.

Ni Aodha, G. (2019), "Urgent need for living wage: $23 \%$ of workers in Ireland are on low pay", available at: https://www.thejournal.ie/workers-in-ireland-on-low-pay-4764896-Aug2019/ (accessed 17 June 2020).

Nugent, C., Pembroke, S. and Taft, M. (2019), Precarious Work in the Republic of Ireland, Nevin Economic Research Institute, Dublin.

Organisation for Economic Cooperation and Development (OECD) (2016), "General government expenditures and revenues per capita”, OECD Factbook 2015-2016: Economic, Environmental and Social Statistics, OECD Publishing, Paris.

Organisation for Economic Cooperation and Development (OECD) (2020a), "OECD economic outlook June 2020", doi: 10.1787/0d1d1e2e-en (accessed 24 July 2020).

Organisation for Economic Cooperation and Development (OECD) (2020b), "Supporting people and companies to deal with the COVID-19 virus: options for an immediate employment and socialpolicy response", available at: https://oecd.dam-broadcast.com/pm_7379_119_119686962r78x4do.pdf (accessed 25 July 2020).

Organisation for Economic Cooperation and Development (OECD) (2020c), "Public employment services in the frontline for jobseekers, workers and employers", available at: https://www.oecd. org/coronavirus/policy-responses/public-employment-services-in-the-frontline-for-employeesjobseekers-and-employers-c986ff92/ (accessed 25 July 2020). 
Office of National Statistics (ONS) (2020), "Coronavirus Job retention scheme official statistics", available at: https://assets.publishing.service.gov.uk/government/uploads/system/uploads/ attachment_data/file/891249/Coronavirus_Job_Retention_Scheme_Statistics_June_2020.pdf (accessed 17 June 2020).

O'Connel, H. and Sheehan, M. (2020), "Who's in charge? Government's relationship with NPHET is straining at the seams", available at: https://www.independent.ie/world-news/coronavirus/ whos-in-charge-governments-relationship-with-nphet-is-straining-at-the-seams-39176591.html (accessed 18 June 2020).

O’Sullivan, M., Turner, T., Lavelle, J., MacMahon, J., Murphy, C., Ryan, L., Gunnigle, P. and O’Brien, M. (2017), "The role of the state in shaping zero hours work in an atypical liberal market economy", Economic and Industrial Democracy, Vol. 41 No. 3, pp. 652-671.

Parliamentary Budget Office (2020), "National debt: an overview", available at: https://data.oireachtas. ie/ie/oireachtas/parliamentaryBudgetOffice/2020/2020-04-21_national-debt-an-overview_en.pdf (accessed 24 August 2020).

Pérez, S.T., Fana, M., González-Vázquez, I. and Fernández-Macías, E. (2020), "The asymmetric impact of COVID-19 confinement measures on EU labour markets", available at: https://voxeu.org/ article/covid-19-lockdown-and-eu-labour-markets (accessed 12 June 2020).

Peck, J. (2001), Workfare States, Guildford, New York, NY.

Peck, J. and Theodore, N. (2000), "Work first': workfare and the regulation of contingent labour markets", Cambridge Journal of Economics, Vol. 24 No. 1, pp. 119-138.

Perkins, D. (2010), "Activation and social inclusion: challenges and possibilities", Australian Journal of Social Issues, Vol. 45 No. 2, pp. 267-287.

Redmond, P. (2020), Minimum Wage Policy in Ireland, Economic and Social Research Institute, Dublin.

Remeikis, A. (2020), "Morrison government announces return to mutual obligation for jobseekers", available at: https://www.theguardian.com/australia-news/2020/may/31/morrison-governmentannounces-return-to-mutual-obligation-for-jobseekers (accessed 11 June 2020).

Seikel, D. and Spannagel, D. (2018), “Activation and in-work poverty”, in Lohmann, H. and Marx, I. (Eds), Handbook on In-Work Poverty, Elgar, Cheltenham, pp. 245-260.

Social Justice Ireland (SJI) (2020), Poverty Focus 2020, Social Justice Ireland, Dublin.

Society of St Vincent de Paul (SVP) (2019), Working, Parenting and Struggling?, SVP, Dublin.

Standing, G. (2011), “Workfare and the precariat”, Soundings, Vol. 47, No. Spring, pp. 35-43.

Theodore, N. (2019), "Governing through austerity: (il)logics of neoliberal urbanism after the global financial crisis", Journal of Urban Affairs, Vol. 42 No. 1, pp. 1-17.

Wilson, T., Cockett, J., Papoutsaki, D. and Takala, H. (2020), "Getting back to work: dealing with the labour market impacts of the Covid-19 recession", available at: https:/www.employmentstudies.co.uk/system/files/resources/files/541.1.pdf (accessed 12 June 2020).

Wright, S. and Dwyer, P. (2014), "Universal credit, ubiquitous conditionality and its implications for social citizenship", Journal of Poverty and Social Justice, Vol. 22 No. 1, pp. 27-35.

Wright, S. and Patrick, R. (2019), "Welfare conditionality in lived experience: aggregating qualitative longitudinal research", Social Policy and Society, Vol. 18 No. 4, pp. 597-613.

Umney, C., Greer, I., Onaran, Ö. and Symon, G. (2018), "The state and class discipline: European labour market policy after the financial crisis", Capital and Class, Vol. 42 No. 2, pp. 333-351.

\section{About the authors}

Dr. Michael McGann is a Marie Sklodowska-Curie Research Fellow in the Department of Sociology and Social Sciences Institute at the National University of Ireland, Maynooth. He specialises in the sociology of work, social policy on employment and the governance of activation with a particular focus on issues related to welfare-to-work and the marketisation of public employment services. He has published widely in the fields of Social Policy, Sociology and Public Policy and Administration, including in 
IJSSP $40,9 / 10$

978 journals such as Journal of Social Policy; Social Policy and Society; Public Administration; Administration and Society; Work, Employment and Society; Policy Sciences; and Policy and Politics. His current research involves a study of the governance of activation in Ireland, looking at the impact of recent marketisation reforms on how public employment services are delivered. Michael McGann is the corresponding author and can be contacted at: michael.mcgann@mu.ie

Prof Mary P. Murphy is Professor in the Department of Sociology, Maynooth University and coordinator of the BA Politics and Active Citizenship. Her research interests include labour market and social security policy, power and civil society and gender. She has published widely in key journals. Key books include Towards a Second Republic (co-authored with P. Kirby Pluto Press, 2011), The Irish Welfare State in the 21st Century (co-edited with F. Dukelow Palgrave, 2016), and Policy Analysis in Ireland (co-edited with J. Hogan, Policy Press, 2021). A contributor to national policy debate she was a member of the National Expert Advisory Group on Taxation and Social Welfare 2011-2014 and the Irish Human Rights and Equality Commission 2013-2017. In 2019 she was appointed by President M.D. Higgins to the Council of State.

Dr. Nuala Whelan is a post-doctoral researcher on the ACA PES: A Collaborative Approach to building a Public Employment Service project at Maynooth University Social Science Institute (MUSSI). She is a Chartered Work and Organisational Psychologist who has worked for 20 years as a practitioner in community-based employment services with clients disadvantaged in the labour market. Her main research interests centre on employability, employment service effectiveness, career guidance models and practice, collaborative working, policy implementation and the potential value of enhancing human capacity for personal, organisational and societal impact. Her current research involves mapping a public employment ecosystem in Ireland and designing an employment guidance tool kit for practitioners working with those most distant from the labour market.

For instructions on how to order reprints of this article, please visit our website: 